\title{
USING MAKE-A MATCH TO IMPROVE THE STUDENTS' READING COMPREHENSION AT MTS GUPPI SAMATA GOWA
}

\author{
Irwanto \\ Universitas Islam Negeri Alauddin Makassar \\ Irwantoar@gmail.com \\ Sitti Nurpahmi \\ Universitas Islam Negeri Alauddin Makassar \\ Sitti.nurpahmi@uin-alauddin.ac.id
}

\begin{abstract}
The main objective of this study is to find out the effectiveness of students ability in Reading comprehension that taught by using Make a Match method. This research was conducted at MTs Guppi Samata Gowa Regency in Academic Year 2016/2017. In this research, the population were students in the first grade. The numbers of population were 50 students. In taking the sample, Class VII A and VII B was chosen by using purposive sampling technique.. Quasi-experimental design was applied in this research with two group pre-test and post-test design. Class VII A was chosen as controlled class by using conventional method (speech method) and Class VII B was chosen as experimental class that taught by using Make a Match method. The instrument used to collect data was reading test, especially multiple choice as a representation of reading and some vocabularies to make a matching in the translation of the words. The result of the data analysis indicated that there was a significant improvement in the students' reading comprehension after being taught using Make a Match method. It was proved by the result of the statistical analysis of the level significance $\mathrm{P}=0.05$ with degree of freedom $(\mathrm{df})=48$ indicated that the $\mathrm{t}$-test values of the students' reading (5.511) was higher than t-table value (2.021). Based on the result analysis, the researcher concludes that of using Make a Match method was effective to improve reading comprehension at the first grade students' of MTs Guppi Samata Gowa, because make a match have some advantages such as each students can be directly involved in answering a question given to them in the from a card, secondly, it can increase the students' activity. Thirdly, it can help avoid students being bored during teaching learning process and make a match method can motivate and encourage students to be more interested and enthusiastic in learning English.
\end{abstract}

Keywords: Students, Reading Comprehension, and Make a match.

\section{A. INTRODUCTION}

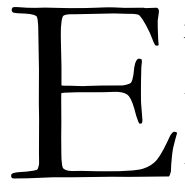

nglish should be mastered by the students, but many of them get difficulties when they try to understand the knowledge from the book, internet, and article. One of the ways that should be done by the students to get the knowledge is reading,

because by reading someone can know the others. It means that we could know something which comes from reading.

According to Nuttal (1982) there are five aspects of reading which the students' should understand to comprehend a text well, they are determining main idea, finding specific information, reference, inference, and vocabulary. Comprehension can be regarded as a 
condition where certainly exist. Besides a pleasure activity that can increase the student's knowledge about the information from the text, in language class also consolidate and extend their knowledge and skill in language.

Based on the statement above, it can be inferred that when the student in reading text, they become the most important thing in reading activity. Comprehension made the students able to determine the essence of the sentence or text and receive the main purpose of reading process. It is necessary for the students because by comprehension students can get aim of reading text, besides that, by comprehending the text the students will find the gist of the text such as an important message or information from the text.

The general problem that the students faced such as; firstly, they did not find main idea of paragraph and meaning of words. Secondly, is they have limited vocabulary, so they are difficult to understand the context of the text. For many students, reading is a hard job to do because reading may be done by spelling word by word. The last is many students feel that reading is boring. They postpone reading until the last of minutes, they realized that they don't have enough time to finish all, moreover in the classroom they get more tasks to read.

Reading is also something crucial and indispensable for the students because the success of their study depends on the greater part of their ability to read. If their reading skills are poor, they are like to fail in their study or at least they had difficulties in making progress. On the other hand, if they have a good ability in reading, they will have a better chance to success in their studying.

Based on the observation in MTs Guppi Samata Gowa which conducted in Monday $15^{\text {th }}$ August 2016 by interviewing both of teacher and students', they had some problems in learning process especially in reading, the problems that they faced including some of the students' did not know the meaning of the difficult words because new words that they got, moreover to understand more what is the content of the book is not effective. The other problems is the students' uninteresting in English because English is difficult to learn and main point is English have many changes in structure, for example in sentences have twelve sentences and also have sixteen sentences in another side, they have confused with it. That's why it needs a good method to help the students solving the problems.

In the other hand, the teacher habit in the classroom activities still used the classical method or speech, the teacher should be creative to find out the method in order to help the students to master the four skills of English language, especially in reading. To increase 


\section{Volume 3, Number 02, December 2017}

students' reading comprehension, there are many methods that can be used, one of them is "Make a Match" method.

To solve the students' problems that they met in their class, especially in reading aspect, Make a Match helped to enhance the reading comprehension of students'. To support this research enhanced their comprehending in reading. It is impossible someone to know something without reading. While teacher is teaching in the class, it is important to make the class fun and active, by using "Make a Match" and it can make all of the students' in the class become more interactiving and involving themselves in to class's activities. Munawar (2013) that "Make a Match" type can make the students' interest, increase and interfere to the interactive situation in the class. It is why the teacher should use "Make a Match" the kind of cooperative learning method to make the students' easier to comprehend the text.

Based on the student's problem above, the English teacher should have an appropriate technique to make reading easier for the students. By applying a good method, teaching reading would create the classroom fun and it also help the teacher to transfer their knowledge. To make specify, the researcher concern to choose "Make a Match" method because it could improve the student's reading comprehension.

Therefore, the research problem of this research was "To what extend the improvement of students' reading comprehension by using Make a Match method?'Then, the research objective was "to find out whether using Make a Match method able to improve the students" reading comprehension at MTs Guppi Samata, Gowa. In addition, this research was beneficial practically in the context for the students is it could help the students' to improve their comprehension in reading and students' can enjoy when they learn English and it can present a happy and funny situation in learning process. To lectures or teachers is, make the students interest in English learning especially in reading text. Besides, this learning model used as effective learning model in the process of learning, and teacher got new innovative method in enhancing their teaching method. The last is to next researcher can be develop in different skill and different participant.

\section{B. LITERATURE REVIEW}

There were some researchers have done the ways of providing reading materials the students in order to increase in learning reading comprehension. Firstly, is Firstly, previous researcher was conducted by Asti Pratiwiningsih (2013) "Using Make a Match Technique in Teaching Reading Comprehension Report Text', she concluded that reading comprehension score of 
students who were taught using Make a Match technique get better achievement to understand report text in reading comprehension and using Make a Match can improve the students' reading comprehension.

Anggraini ( 2016) found that using chunking strategy effective to improve the students reading comprehension in which the mean score of students' post-test of experimental group was 56. It was higher than the controlled group that was only got 23 . This research was successful to solve the students' problem in comprehending the text by using chunking strategy.

Nur and Ahmad ( 2017) reported that the implementation Interactive Approach was successful since the criteria of success were achieved. The first criterion was $70 \%$ of students could pass the target score 70 based on the KKM. The finding showed that 74.57 of students had already achieved the target score. besides, the second criterion was the students who become more active involved in teaching learning process. the result of observation checklist showed that through Interactive Approach method, the students were more creative confident in the classroom especially reading activity. Based on the finding mentioned above, the researcher suggest that English teacher could implement Interactive Approach method in teaching reading in order to improve students in learning Englsih reading.

Another study was done by Komang Wastawan et al (2010), the research found that there was a significant difference students reading comprehension after being taught through Make a Match type of cooperative learning. The findings of the research show that Make a Match Method could improve the students the students reading comprehension. It was proved by data that shows the mean of the students' scores in pre-test (50.88) was higher than the mean of the students' scores in post-test (75.59).

From the consideration, the researcher decided to applied same method in teaching reading comprehension to find out the students' comprehending in MTs Guppi Samata, Gowa.

\section{Make a match}

Make a Match method is one of the co-operative learning methods developed and introduced by Lorna Curran in 1994. According to Curran (1994) the basic principle of Make a Match is the students find or match a partner while they are learning a concept or a particular topic in an interesting classroom atmosphere. To provide more understanding about the technique, some information is provided as follows. Make a Match is one of the co-operative learning which can be used in all lesson. 


\section{Volume 3, Number 02, December 2017}

Make a match method is a kind of game also, where students have to find their partner. In this method, the students are divided into two groups, group A and group B. Each of the students in each group get one card. The students in group A get the topic cards while the students in group B get the simple description cards. After they find their matches, they have to report it to the teacher and the last step is the teacher asks them to compose sentences based on the words they got on their cards. According to Munawar (2013) adds that the Make a Match method has several advantages: First, each student can be directly involved in answering a question given to them in the form of a card. Secondly, it can increase the students' creativity through matching the cards. Thirdly, it can help avoid students being bored during the teaching-learning process. The last is it can create a more interesting classroom atmosphere.

\section{Reading Comprehension}

Nuttal (1982) defines reading comprehension as the ability of understanding and interpreting information in text correctly. Meanwhile smith and Johnson (1980) states that reading comprehension is understanding, evaluating utilizing of information and gained through the interaction between reader and author. There are various levels in hierarchy of thinking. According to Smith \& Johnson (1980) categories the level of reading comprehension skills level into four levels, such as literal reading, interpretative reading, critical reading and creative reading.

In addition, Nuttal (1982) stated that there are three vital processes of reading comprehension. Firstly, is about previewing - scanning, searcbing, reading bit (heading, illustrations, and paragraph) and setting up some expectation. Secondly, predicting, it makes guesses which are informed these expectation, knowledge of the subject, the writer, the type of the time writing, of the likely concepts, contents or conventions. The last is is about checking: confirming, enhancing or extending predictions or pre-knowledge by using features within the text or resources outside it.

\section{RESEARCH METHOD}

In this research, the researcher applied Quasi Experimental Research. It aims that to found out the effectiveness of using Make a Match to improve the students' reading comprehension at MTs Guppi Samata, Gowa. In this design involved into two groups, the experimental group and the control group.

\begin{tabular}{cccc}
\hline $\mathrm{E}$ & $\mathrm{O}_{1}$ & $\mathrm{X}$ & $\mathrm{O}_{2}$ \\
\hline $\mathrm{C}$ & $\mathrm{O}_{3}$ & & $\mathrm{O}_{4}$ \\
\hline
\end{tabular}


Where:

E : Experimental group

C : Control group

$\mathrm{X} \quad$ : Treatment

$\mathrm{O}_{1} \& \mathrm{O}_{3} \quad$ : Pre-test

$\mathrm{O}_{2} \& \mathrm{O}_{4}$ : Post- test

The variables of this research were students' reading comprehension as dependent variables and Make a Match method as independent variable.

The researcher took the students in MTs Guppi Samata Gowa in academic year 2016/2017, which located on H. Yasin Limpo street No. 36 Samata, Gowa regency. The population of this research was the students' at first grade of MTs Guppi Samata, Gowa. There were two classes and each class consists of 25 students'. The total of the students were 50 students. This research used purposive sampling. In purposive sampling, the researcher selected a sample that is believed to be representative of a given population. It means that the researcher took one class of the students.

The researcher used the reading test to collect the quantitative information about the real objective. The kind of test is 20 numbers multiple choice and 5 numbers make a matching some words. In this case the researcher used a test as tool to determine the ability of students' to understand the material being taught. In reading test the researcher made it separate each the sentences, the purpose to make like that is to give the students a chance to looking for their partner from the text that they are gotten, so they would Make a Match to know the continuing the text, and the totality of the test is twenty five numbers.

To collect data, the researcher used some procedures, such as pre-test, treatment, and post-test. Before doing treatment, the students' were given pre-test to know the students comprehension. It intend to see the students' prior knowledge on reading comprehension. After giving pre-test, the students were treated for six meeting in class VII B by implementing Make a Match method, and post-test is a form of question given after material has been delivered. In short, the post test is currently teaching materials evaluation end of the day was given. It aims that to know their improvement knowledge about reading.

In analyzing the data, the researcher used descriptive and inferential statistics.

\section{FINDINGS AND DISCUSSIONS}


Volume 3, Number 02, December 2017

\section{The Findings of Research}

The table1 and 2 showed the classification of the students' reading comprehension at the first grade of MTs Guppi Samata Gowa in pretest and post test scores in experimental class.

Table 1

The rate percentage of score experimental class in pre-test

\begin{tabular}{|c|c|c|c|c|}
\hline No. & Classification & Score & Frequency & Percentage \\
\hline 1. & Excellent & $96-100$ & 0 & $0 \%$ \\
\hline 2. & Very good & $86-95$ & 0 & $0 \%$ \\
\hline 3. & Good & $76-85$ & 0 & $0 \%$ \\
\hline 4. & Fairly good & $66-75$ & 3 & $12 \%$ \\
\hline 5. & Fair & $56-65$ & 3 & $12 \%$ \\
\hline 6. & Poor & $46-55$ & 3 & $12 \%$ \\
\hline 7. & Very poor & $0-45$ & 16 & $64 \%$ \\
\hline & Total & 25 & $100 \%$ \\
\hline
\end{tabular}

Table 1 shows that the rate percentage and frequency of the student's experimental class in the pre-test, the students got neither excellent nor very good and good score, 3 (12\%) students got fairly good score, fair and poor score and 16 (64\%) students got very poor score. It means that, the students' score before given treatment were low.

\section{Table 2}

The rate percentage of score experimental class in post-test

\begin{tabular}{|c|c|c|c|c|}
\hline No. & Classification & Score & Frequency & Percentage \\
\hline 1. & Excellent & $96-100$ & 1 & $4 \%$ \\
\hline 2. & Very good & $86-95$ & 6 & $24 \%$ \\
\hline 3. & Good & $76-85$ & 5 & $20 \%$ \\
\hline 4. & Fairly good & $66-75$ & 5 & $20 \%$ \\
\hline 5. & Fair & $56-65$ & 7 & $28 \%$ \\
\hline 6. & Poor & $46-55$ & 1 & $4 \%$ \\
\hline 7. & Very poor & $0-45$ & 0 & $0 \%$ \\
\hline & \multicolumn{2}{|c|}{ Total } & 25 & $100 \%$ \\
\hline
\end{tabular}

Table 2 shows that in the post-test there were students 1 (4\%) got in excellent, 6 (24\%) got in very good, 5 (20\%) students got good score and fairly good score, 7 (28\%) students got 
fair score and $1(4 \%)$ students got fair and there were not students got very poor score. It means that, the using of make a match method was effective to improve the student's reading comprehension.

After calculating the result of the students score, the mean score and standard deviation of both classes can be presented in the following table:

Table 3

The mean score and standard deviation of pretest and posttest both classes

\begin{tabular}{|l|l|l|l|l|l|}
\hline \multirow{2}{*}{ Class } & \multicolumn{2}{|c|}{ Mean score } & \multirow{2}{*}{ Range } & \multicolumn{2}{c|}{ Standard Deviasi } \\
\cline { 2 - 4 } & Pre-test & Post-test & & Pre-test & Post-test \\
\hline Experimental & 45.44 & 74.28 & 28.84 & 12.214 & 14.684 \\
\hline Control & 54.72 & 51.52 & -3.2 & 13.588 & 15.549 \\
\hline
\end{tabular}

The table 3 shows that, the mean score of experimental class in pre-test was (45.44) and the standard deviation of experimental class was (12.214), and the mean score of controlled class in pre-test (54.72) and its standard deviation was (13.588). While the mean score of experimental class in post-test of controlled was (74.28) and the standard deviation of experimental class was (14.684), the mean score of controlled class in post-test was (51.52) and standard deviation was (15.549). It can be concluded from both of the tests; the experimental class gained the greater mean score than the controlled group.

The significance score between experimental score and control class can be known by using the t-test. The result of the t-test can be seen in the following table.

\section{Table 4}

Distribution the value test of $\mathrm{t}$-test and $\mathrm{t}$-table in post-test

\begin{tabular}{|l|l|l|}
\hline Variable & t-test value & t-table value \\
\hline Post-test & 5.511 & 2.021 \\
\hline
\end{tabular}

The table above showed that $\mathrm{t}$-test value was greater than $\mathrm{t}$-table. The result of the test showed there was significant difference between $t$-table and t-test $(5.511>2.021)$, it means that, $\mathrm{t}$-table was smaller than $\mathrm{t}$-test.

The result of the t-test statistical analysis showed that there was significant difference between the experimental class who got treatment by using Make a Match method with controlled class who taught by conventional method. The statement was proved by the t-test 


\section{Volume 3, Number 02, December 2017}

value (5.511) which was higher than t-table value (2.021), at the level of significance $(\alpha) \quad 0.05$ and the degree of freedom (df) 48.

\section{Discussion}

The method of Make a Match is one of the cooperative learning that learning results obtained through cooperation with others. The cooperation can be done in a variety of forms both groups and in a formal learning environment that occur naturally. Besides, learning community correlates with the real object or daily life to make students easier to understand the material because the students' can get helping from his/her friend.

Make a match method is a suitable method applied in the classroom in teaching reading at first grade of MTs Guppi Samata Gowa. The result of this research showed that this method have influence on improving students' reading comprehension. Make a Match method is a method that designed for giving student a skill to overcome the problems. So that, they become addicted to learn more and increased students' reading.

The researcher found that applied Make a match method was effective in improving the students' reading. It was indicated by the total pre-test of experimental group that was 1134 with the mean score 45.44 and it's posttest was 1857 with mean score was 74.28. Meanwhile, the total of the pre-test and post-test of the controlled group was 1368 with the mean score was 54.72 and it's the post test was 1288 with mean score 51.52 . The result of the t-test both groups, experimental and controlled group was higher than t-table result $(5.511 \geq 2.021)$.

The researcher concluded that the using of Make a Match method in teaching reading is effective. It was proved by the result of the data analysis after being with t-table (2.021) with the t-test (5.511). Moreover, the researcher also are supported from Asti Pratiwiningsih (2013) entitled "Using Make a Match technique in Teaching Reading Comprehension report Text", she concluded that reading comprehension score of students who are taught using Make a Match technique get better achievement to understand report text in reading comprehension and using make a match can improve the students' reading comprehension.

To sum up, based on the the result of this study, which showed the students' scores were higher after the treatment in experimental class using Make a Match method. The use Make a Match method for teaching reading was surely beneficial to increase students' ability. In summary, the researcher asserted that Make a Match method was important to apply on teaching reading.

\section{E. CONCLUSION AND SUGGESTION}




\section{Conclusion}

From the discussion in previous chapter, it can be concluded that using of Make a Match method is more effective than conventional (speech method) method because Make a Match method improved the students reading comprehension. The students reading comprehension towards descriptive text before using Make a Match method was very poor (16 or (64\%). It was different from the students reading comprehension after using Make a Match Method.

The data analysis there was significance improvement of the students' post-test of experimental class from 25 students, where there were 1 4\%) students got excellent, 6 (24\%) students got very good and good score, 7 (28\%) students got fair and, 1 (4\%) students poor score and there were not students got in very poor score.

It can be concluded that the main score of the students increase from the very poor (45.44) become fairly good (74.28). The test value was 5.511 and the table was 2.021, it meant that $\mathrm{H}_{1}$ was accepted explaining that Make a Match was effective to improve the students reading comprehension of MTs Guppi Samata Gowa and the null hypothesis $\left(\mathrm{H}_{0}\right)$ was rejected.

\section{Suggestion}

For the Teacher or Lecturer, Make a Match method should be considered as an alternative method to be used by English teachers in teaching vocabulary in the classroom since it may be effective to increase the students' reading comprehension. Indeed, this research was focused on teaching reading. This does not mean that the Make a Match method can only be used in teaching these materials but it may also be used in teaching other materials.

Therefore, English teachers are suggested to try using the Make a Match method in teaching all types of texts. Second, English teachers applying this method should follow the steps suggested in the Make a Match technique in teaching reading to increase the students' participation and maximum scores, possibly the Make a Match method needs to be used many times not just a couple of times as in this study to really make a significant improvement in the reading of the students.

For the Students, Students should always be active in teaching-learning process. They must study hard if they want to be successful in mastering English. It is suggested to the students who need improvement in their ability especially in reading skill may try to use more the Make a Match method in different chance. 


\section{Volume 3, Number 02, December 2017}

To the next researcher, it is suggested to other researchers to complete this research by conducting any other researches in Make a Match method. Based on the explanation above the writer would like to suggest other researcher, that the result of the study can be used as additional reference for further research with different sample and occasions. This research has many limitations and more researches should be conducted on this topic.

\section{REFERENCES}

Anggraini, R. (2016). The effectiveness of Using Chunking Strategy To Improve Students'reading Comprehension At The Second Year Of Smp Negeri 2 Barombong. ETERNAL (English, Teaching, Learning, and Research Journal), 1(2), 299-312.

Aqib, Zainal.(2013) Model- Model, Media, dan Strategi Pembelajaran Kontekstual (Inovatif). Bandung: Yrama Widya.

Arikunto, Suharsimi. (2006). Prosedur Penelitian Suatu Pendekatan Praktik. Jakarta: PT Rineka Cipta.

Baso, Jabo. (2008). English Language Testing. Makassar: Badan Penerbit UNM.

Curran, L. (1994) Language Arts and Cooperative Learning: Lesson for the Title Ones. San Clemente, C.A:Kagan Publisher.

Harmer, Jeremy. (2007). The practice of English Language Teaching. $3^{\text {rd }}$ Edition. Longman.

Huda, Miftahul. (2015) Cooperative Learning:Metode, Tehnik, Struktur, dan Model Penerapan. Yogyakarta: Pustaka Pelajar.

Huda, Miftahul. (2015) Model-Model Pengajaran dan Pembelajaran:Isu-Isu Metodis dan Pragmatis. Yogyakart:Pustaka Pelajar.

Isjoni. (2007). Cooperative Learning, Efektivitas Pembelajaran Kelompok. Bandung: Alfabeta.

Kasihani. (2007). English for Young Learners, Jakarta: PT Bumi Aksara.

Kreidler, Charles W. (1998). Introducing English Semantics, New York: British Library:

Latief M. Adnan. (2013). Research Methods on Language Learning: An Introduction. Malang: UM Press.

Lie Anita.(2008) Cooperative Learning: Pembelajaran di Ruang-Ruang Kelas. Jakarta: Grasindo.

Muijs, Daniel. and David Reynold. (2008). Effective Teaching:Teori dan Aplikasi. Yogyakarta: PT. Pustaka Pelajar.

Munawar. (2013). Konsep Pengembangan Belajar dan Pembelajaran Berbasis Pendidikan Karakter, Ikbtiar Membangun Keseimbangan IQ, EQ \& SQ. Yogyakarta: Kurnia Kalam Semesta.

Nasr. (1984) How to Teach Reading. California:Addison Wesley Publishing. 
Nurpahmi, S. (2013). An Introduction to English for Specific Purposes. Makassar: Alauddin University Press.

Nurpahmi, S. (2014). English for Specific Purposes: An Integrated Approach. Makassar: Alauddin University Press.

Nurpahmi, S. (2015). Improving Listening Skill By Activating Students'prior Knowledge. ETERNAL (English, Teaching, Learning, and Research Journal), 1(1), 28-38.

Nur, A. H., \& Ahmad, D. (2017). Improving Students'reading Skill Through Interactive Approach At The First Grade Of SMAN 1 Mare, Bone. ETERNAL (English, Teaching, Learning, and Research Journal), 3(1), 44-56.

Nuttal, Cristine. (1982) Teaching Reading Skills in a Foreign Language. London:Heinemanm Educational Books.

Pratiwiningsih, Asri. (2013) Make a Match Technique in Teaching Reading Comprehension Report Text. Thesis of STKIP Jombang.

Rahman, I. F. (2015). The Implementation Of Collaborative Strategy Reading (Csr) And Its Effects On Students'reading Comprehension. ETERNAL (English, Teaching, Learning, and Research Journal), 1(1), 39-56.

Rivers. M. Wilga. (1981). Teaching Foreign-Language Skills. Chicago: The University of Chicago press.

Slavin. E, Robert. (2005). Cooperative Learning: Teori, Riset dan Praktik. Bandung: Nusa Media.

Smith, Richardj, and D dale D Johnson. (1980). Teaching Reading: A Handbook. USA:St. Martin Press.

Sugiyono. (2014). Metode Penelitian Kuantitatif Kualitatif dan R\&D. Bandung: Alfabeta.

Suprijono, Agus. (2014). Cooperative Learning: Teori dan Aplikasi PAIKEM. Yogjakarta: PT. Pustaka Belajar.

Sukestiyanto. (2013). Statistika Dasar. Yogyakarta : C.V Andi Offset.

Zaini. H. Munthe and Aryani S. (2008). Strategi Pembelajaran Aktif. Yogyakarta: Pustaka Insan Madani.

Wahyuni, Sri. (2010). The Effectiveness of Using Make-A Match Method in Teaching Reading Comprehension to the First Grade Students of SMPN 02 Sulang Rembang”. Thesis of State University of Semarang. 